\title{
Perancangan Sistem Informasi Layanan Pelaporan Kerusakan Mesin Electronic Data Capture
}

\author{
Agus Saifullah $^{1 *}$, Bakhtiar Rifai ${ }^{2}$, Vito Triantori ${ }^{3}$ \\ 1,2,3 Jurusan Teknik Informatika, STMIK Nusa Mandiri , Jakarta \\ email: ${ }^{1}$ ases8085@gmail.com, ${ }^{2}$ bakhtiar.bri@nusamandiri.ac.id, ${ }^{3}$ tugasvto.bsinuri@gmail.com
}

$\begin{array}{ccc}\text { Diterima } & \text { Direvisi } & \text { Disetujui } \\ 09-12-2019 & 12-12-2019 & 16-12-2019\end{array}$

\begin{abstract}
Abstrak - Pada sebuah perusahaan khususnya dalam memberikan pelayanan kepada toko pengguna mesin EDC ( Electronic Data Capture) perlu adanya kecepatan pada penanganan setiap masalah yang sudah dilaporkan. EDC adalah sebuah mesin yang berfungsi sebagai sarana penyedia transaksi dan alat pembayaran yang penggunaannya dengan cara memasukkan atau menggesek kartu ATM, kartu debit maupun kartu kredit dalam suatu bank maupun antar bank, serta dilengkapi dengan fasilitas pembayaran lainnya yang terkoneksi secara realtime. Sehingga perlu adanya aplikasi yang sistematis dalam penyelesaian masalah dilapangan. Semua penanganan masalah, pencatatan laporan, serta perhitungan masalah yang masih dilakukan secara manual. Untuk mengatasi masalah tersebut maka penelitian dilakukan untuk merancang dan membuat suatu sistem informasi layanan pelaporan kerusakan yang dinamis pada PT.Visionet Data Internasional sehingga dapat mempermudah karyawan dalam melakukan pekerjaannya serta dapat mengefesiensikan waktu pengerjaan. Perangkat lunak yang digunakan untuk membuat program aplikasi ini diantaranya Xampp, Hypertext Prepocessor (PHP), My Structure Query Language (MySQL), Macromedia Dreamweaver. Dengan adanya aplikasi ini hasil yang ingin dicapai adalah untuk mempercepat setiap penanganan masalah dan mempermudah karyawan dalam memberikan laporan sehingga dapat mengefesiensikan waktu dalam proses pekerjaan juga membantu mencari dan mengetahui masalah yang ada serta memberikan solusi alternative terhadap permasalahan yang dihadapi.
\end{abstract}

Kata Kunci: Perancangan, Sistem Informasi, Layanan, EDC, MySQL

\section{PENDAHULUAN}

"Electronic Data Capture (EDC) adalah
alat elektronik yang digunakan transaksi pembayaran atau perbankan lainya dengan cara gesek untuk kartu debit magnetic, dip untuk kartu chip, atau dengan menempelkan kartu seperti EMoney"(Cermati.com, 2019). Penggunaan mesin EDC sangat dibutuhkan dan terus meningkat khususnya para pedagang untuk kelancaran bisnisnya. Secara otomatis mesin EDC harus dilakukan pemeliharaan yang dapat mengurangi tingkat kerusakan mesin dan memperpanjang umur suatu mesin. Serta kemudahan pelanggan dalam memberikan laporan ketika mengalami kendala. Sehingga diharapkan sistem layanan pelaporan kerusakan mesin EDC tersebut akan dapat memberikan keuntungan baik serta pengaruh pada kinerja mesin tersebut. Aplikasi pelayanan berbasis Web dapat dijadikan sebagai sarana yang sangat efisien. "Website dapat didefinisikan merupakan kumpulan dari keseluruhan halaman- halaman web yang terdapat dari sebuah domain yang mengandung informasi"(Agus \& Safitri, 2015).

Pelayanan pengaduan kerusakan memiliki peranan yang sangat penting karena dapat memberikan solusi atas keluhan dalam kurun waktu yang singkat. Setiap permasalahan yang telah selesai ditindaklanjuti akan secara otomatis terdokumentasi dengan baik sehingga dapat dijadikan referensi serta dapat menyajikan laporan untuk memenuhi kebutuhan informasi dalam suatu perusahaan yang dapat diakses dengan cepat dan mudah sehingga, dapat menghasilkan solusi yang tepat dalam mengatur sumber daya yang ada(Darmawan \& Senjaya, 2017).

"Mempertahankan kepuasan pelanggan adalah hal yang sangat penting untuk meningkatkan pendapatan. Kepuasan pelanggan dapat diperoleh disaat ekspektasi pelanggan sesuai dengan produk atau layanan perusahaan"(Gonius, 2013).

PT. Visionet Data Internasional, merupakan perusahaan yang bergerak dalam bidang jasa pemeliharaan mesin Electronic Data Capture (EDC). Untuk saat ini jumlah mesin EDC yang dilakukan pemeliharaan sekitar 30.000 unit di wilayah Jabodetabek. Dan rata-rata laporan yang diterima oleh tim Helpdesk terkait dengan kendala teknis pada mesin EDC perharinya ada pada kisaran angka 100 pelaporan. Permasalahan yang terjadi adalah setiap kejadian kerusakan pada mesin EDC, pihak pedagang masih melaporkan dengan komunikasi telepon dan pencatatan juga masih dilakukan secara manual termasuk penugasan pekerjaan ke tim teknisi yang ada dilapangan. Sehingga banyak informasi laporan masalah tidak 
tertangani oleh tim Helpdesk serta banyak terjadinya telepon masuk terabaikan yang menyebabkan lambatnya penanganan masalah dan tentunya hal ini berpotensi terjadinya keluhan keras dari pengguna mesin EDC atau Merchant.

Berdasarkan permasalahan diatas, penulis tertarik untuk merancang suatu sistem informasi yang dapat digunakan untuk pencatatan laporan para pengguna mesin EDC sebagai upaya untuk kecepatan penanganan masalah yang terjadi tersebut dan pastinya mengetahui dari awal proses keluhan sampai selesai perbaikan dan bisa memberikan laporan secara sistematis. "Sistem Informasi secara teknis dapat didefinisikan sebagai sekumpulan komponen yang saling berhubungan, mengumpulkan atau mendapatkan, memproses, menyimpan dan mendistribusikan informasi untuk menunjang pengambilan keputusan dan pengawasan dalam suatu organisasi"(Syukron \& Hasanah, 2015).

"Perancangan adalah sebuah proses yang mendefinisikan sesuatu yang akan dikerjakan dengan menggunakan teknik yang bervariasi serta di dalamnya melibatkan deskripsi mengenai arsitektur serta detail komponen dan juga keterbatasan yang akandialami dalam proses pengerjaannya"(Nugroho, Safirman, Studi, \& Informatika, 2015).

"Informasi pada dasarnya adalah himpunan data yang telah di olah menjadi suatu yang memiliki arti dan kegunaan yang lebih luas"(Muhidin, Kharie, \& Kubais, 2017).

\section{METODE PENELITIAN}

A. Metode Pengumpulan Data

1) Metode Observasi

Tahap observasi ini penulis melakukan pengamatan langsung dengan tujuan penulis dapat mengetahui permasalahan serta menganalisa bagaimana alur proses dan penanganan permasalahan EDC tersebut di PT. Visionet Data Internasional.

2) Metode Wawancara

Metode ini dilakukan dengan cara wawancara pada seseorang yang bertanggung jawab atau melakukan diskusi dengan seseorang yang mengerti terhadap proses sistem layanan pengaduan pada EDC di Bank tersebut yang sedang berjalan di PT. Visionet Data Internasional

3) Metode Studi Pustaka

Dalam melakukan studi pustaka penulis melengkapi kekurangan-kekurangan data yang diperoleh dari studi lapangan. Pengumpulan data dengan cara mengambil dari sumber-sumber media cetak maupun elektronik yang dapat dijadikan acuan pembahasan masalah. Penulis membaca dan mempelajari buku-buku dan situs yang penulis kunjungi dapat dilihat pada daftar pustaka.
B. MetodePengembangan Sistem

Dalam melakukan penelitian ini penulis menggunakan metode System Development Life Cycle (SDLC) yang akan di gunakan pada tahap pengembangan sistem yang di usulkan, Pada metode ini terdapat tahapan-tahapan antara lain sebagai berikut :

a. Analisa Kebutuhan Software

Dalam penyelesaian permasalahan penginputan data keluhan di PT. Visionet Data Internasional, maka dibutuhkan sebuah aplikasi sebagai penunjang pekerjaan tersebut.

b. Design

Pada tahapan Desain ini penulis perlu adanya kebutuhan sistem aplikasi rancangan database dengan UML yang terdiri dari: Use Case Diagram, Activity Diagram, Componen Diagram, Deployment Diagram, Entity Relationship Diagram.

c. Code Generation

Tahap ini pemodelan yang sudah di buat di terjemahkan ke dalam bahasa pemrograman php, mysql dengan Framework Bootstrap, Code Igniter.

d. Testing

Penulis melakukan pengujian menggunakan Black box testing untuk mengetahui apakah web yang dibuat telah sesuai dengan desainnya dan masih terdapat kesalahan atau tidak.

e. Support

Maintenance atau perawatan diperlukan agar sistem yang telah terpasang dapat berfungsi sebagai mestinya. Dengan melakukan sistem maintenance

Secara berkala maka dapat mencegah permasalahan pada sistem.

\section{HASIL DAN PEMBAHASAN}

\section{A. Analisis Sistem Berjalan}

Sesuai hasil observasi dan wawancara yang sudah dilakukan di PT. Visionet Data Internasional bahwa dapat diambil kesimpulan dari sistem berjalan yaitu dalam penanganan pelaporan permasalahan masih kurang efektif dimana dilakukan dengan cara konvesional, ketika merchant melaporkan masalah masih menggunakan media telepon serta dalam penanganan penyelesaian kunjungan teknisi ke lokasi merchant menggunakan media kerta sebagai Surat Perintah Kerja.

\section{B. Pembahasan}

Dalam pengembangan sistem informasi layanan pelaporan kerusakan mesin EDC menggunakan model waterfall yang terdiri dari analisis, desain, pengodean, pengujian, support. 
"Model SDLC memiliki beberapa model, seperti Model Waterfall atau yang sering juga disebut model sekuensial linier atau alur hidup klasik. Model air terjun menyediakan pendekatan alur hidup perangkat lunak secara sekuensial atau terurut mulai dari analisis, desain, pengodean, pengujian dan tahap pendukung"(Rosa \& Shalahuddin, 2018)

\section{Rancangan Program}

Dalam setiap perancangan program atau aplikasi dibutuhkan beberapa komponen pendukung penting agar program aplikasi beroperasi secara maksimal, efektif,dan efisien. Sedangkan penggambaran sistem menggunakan UML (Unified Modelling Language).

\section{1) Use Case Diagram}

Use Case diagram menggambarkan kegiatan atau juga interaksi yang saling berkesinambungan (continue) antara aktor dan juga sistem.Bisa juga sebagai salah satun teknik secara umum yang digunakan, untuk mengembangkan perangkat lunak (software) atau sistem informasi, guna memperoleh kebutuhan fungsional dari sistem yang ada

Berikut adalah rancangan Use Case Diagram pada sistem PT Visionet Data Internasional.

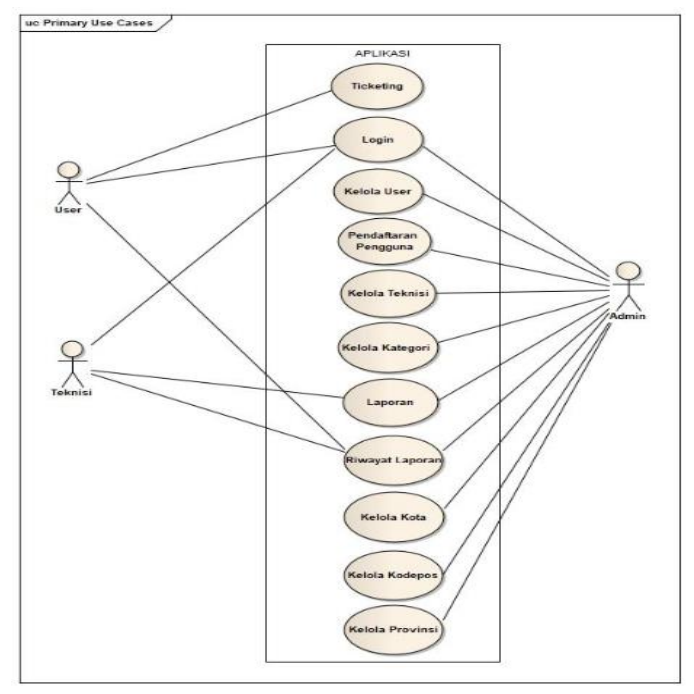

Sumber: Penelitian 2018

Gambar. 1 Use case diagram

\section{2) Activity Diagram}

Activity Diagram adalah diagram yang menggambarkan aliran kerja (worlflow) atau aktivitas dari sebuah sistem atau proses bisnis. Diagram aktivitas juga dapat menggambarkan alur kontrol secara umum atau secara global dari aktivitas-aktivitas atau tindakan yang terjadi dalam suatu sistem informasi.Di bawah ini merupakan activity diagram rancangan aplikasi yang diusulkan.

\section{a. Activity Diagram Login}

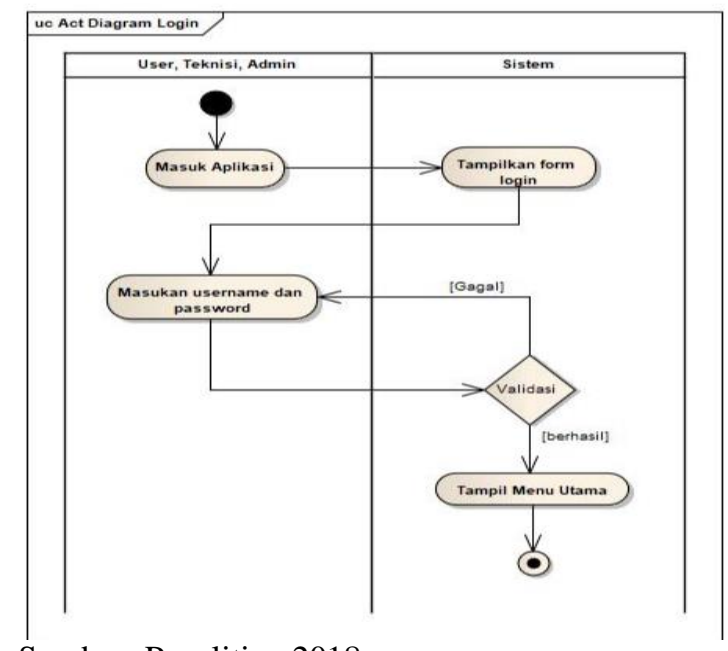

Sumber: Penelitian 2018

Gambar. 2 Activity Diagram Login

\section{b. Activity Diagram Ticketing}

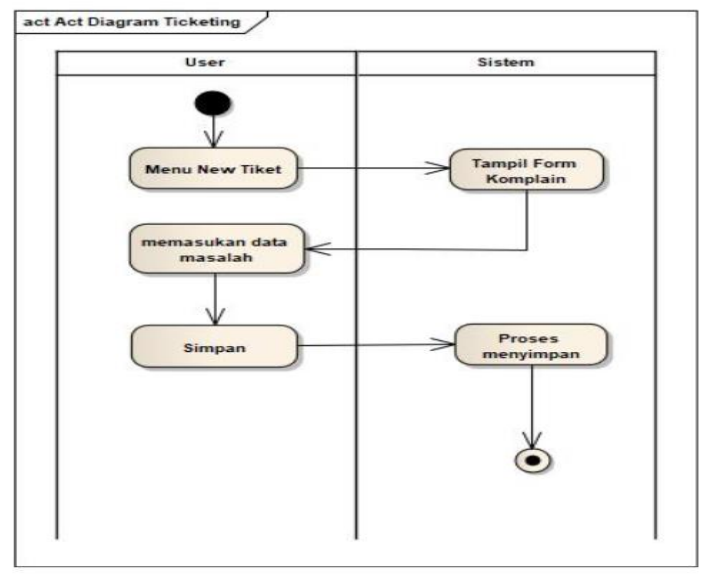

Sumber: Penelitian 2018

Gambar. 3 Activity Diagram Pembuatan Tiket Keluhan

c. Activity Diagram Assignment Ticketing

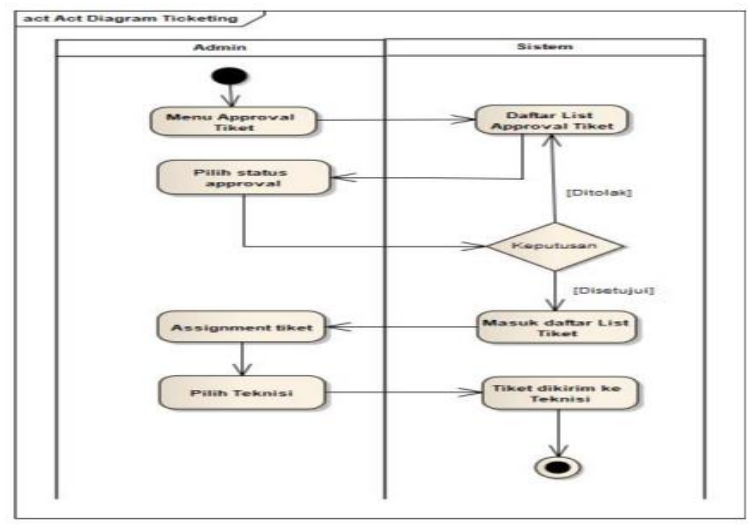

Sumber: Penelitian 2018

Gambar.4 Activity Diagram Assignment Tiket 
d. Activity Diagram Pendaftaran pengguna

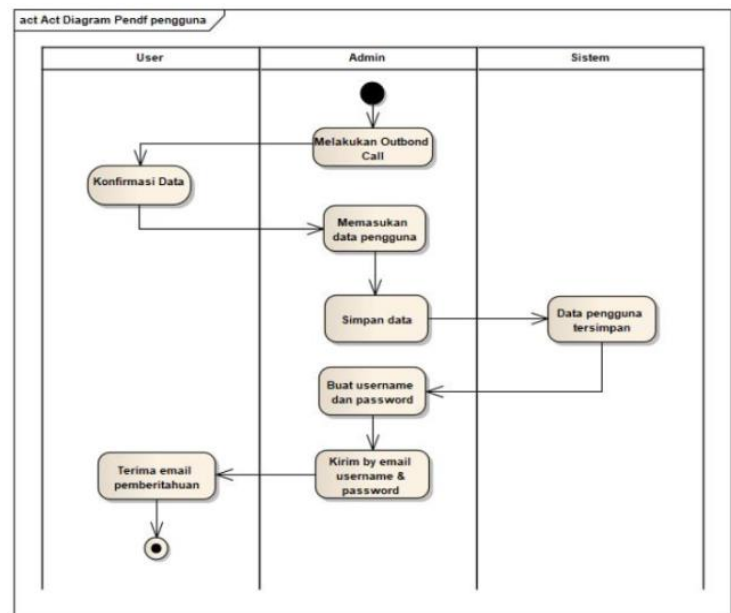

Sumber: Penelitian 2018

Gambar. 5 Activity Diagram Pendaftaran

Pengguna

e. Activity Diagram Kelola data User

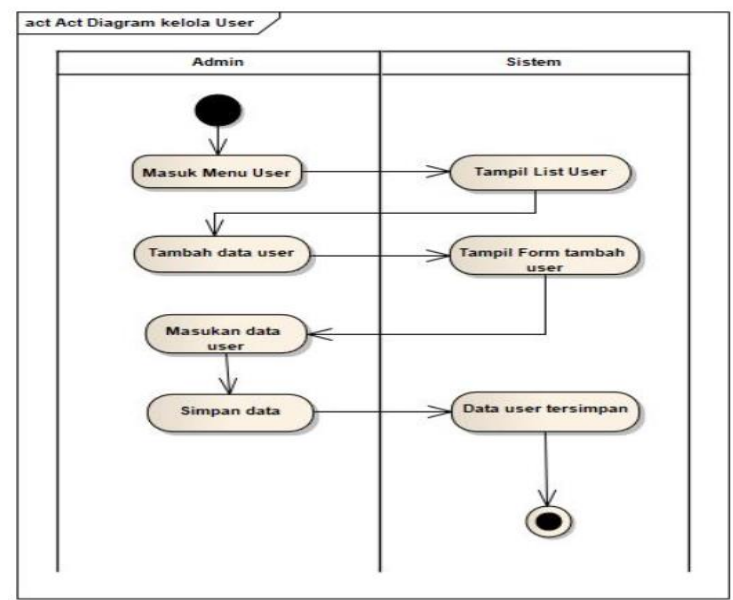

Sumber: Penelitian 2018

Gambar. 6 Activity Diagram Kelola Data User

f. Activity Diagram Kelola Data Teknisi

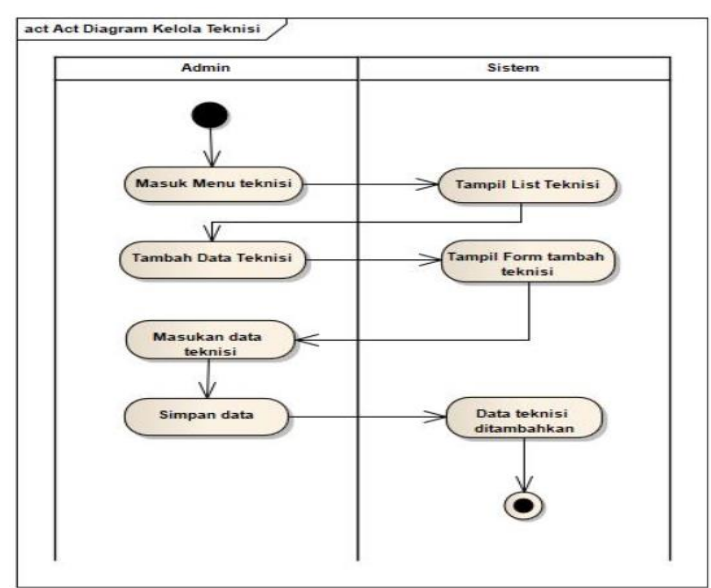

Sumber: Penelitian 2018

Gambar. 7 Activity Diagram Kelola data teknisi g. Activity Diagram Laporan

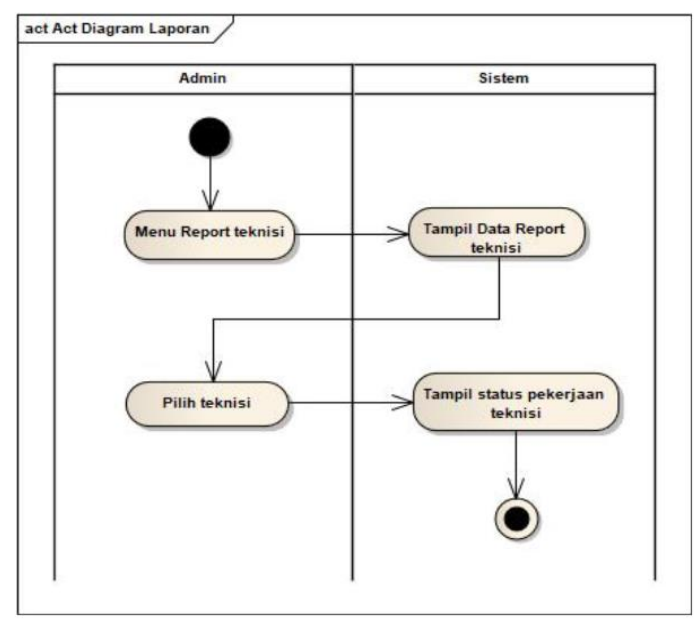

Sumber: Penelitian 2018

Gambar. 8 Activity Diagram Laporan

h. Activity Diagram Pelaporan teknisi

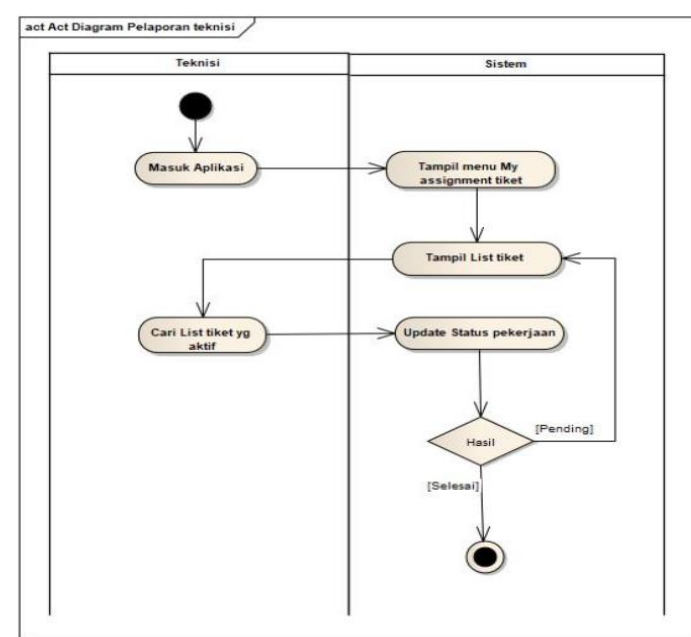

Sumber: Penelitian 2018

Gambar. 9 Activity Diagram Pelaporan teknisi

D. Database

1) Entity Relationship Diagram (ERD)

Entity Relationship Diagram menjelas- kan hubungan antara data dalam basis data yang terdiri dari objek-objek dasar yang mempunyai hubungan atau relasi antar objek - objek tersebut. ERD yang digunakan pada sistem ini adalah sebagai berikut : 


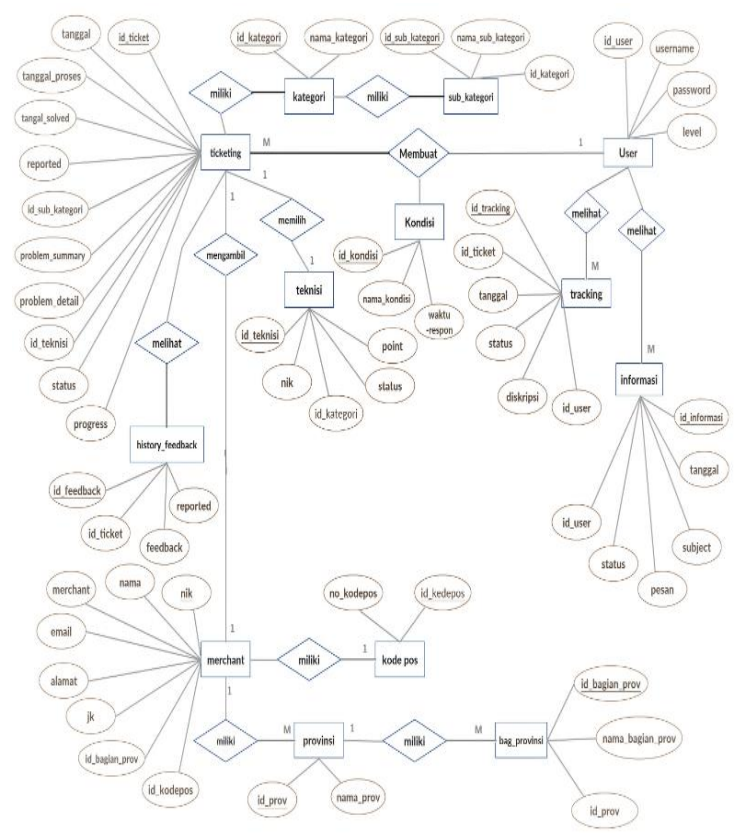

Sumber: Penelitian 2018

Gambar. 10 Entity Relationship Diagram (ERD)

\section{2) Logical Record Structure (LRS)}

Penggambaran dari Logical Record Structure (LRS) yang ada pada Perancangan Sistem Informasi Layanan Pelaporan Kerusakan Mesin EDC adalah sebagai berikut :

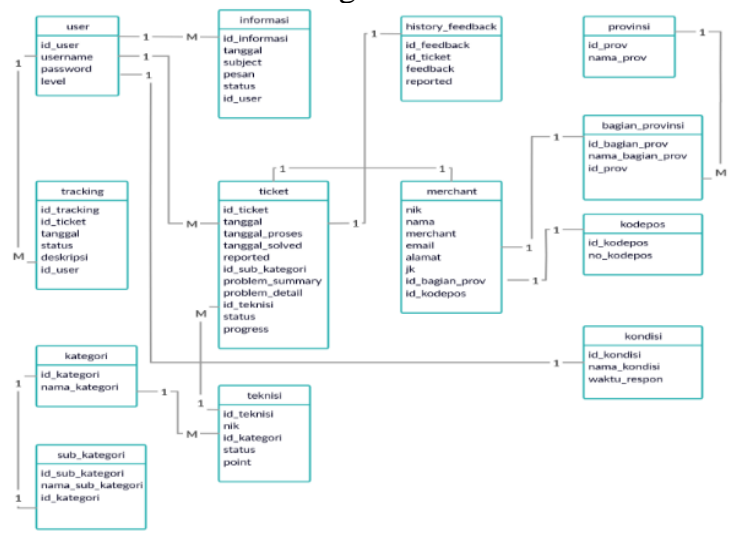

Sumber: Penelitian 2018

Gambar. 11 Logical Record Structure (LRS)

E. Implementasi Antarmuka

a) Perancangan Form Login

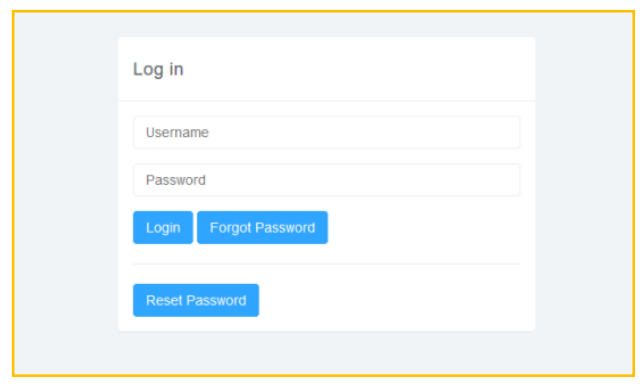

Sumber: Penelitian 2018

Gambar. 12 Form Login b) Menu Utama dan Dashboard Admin

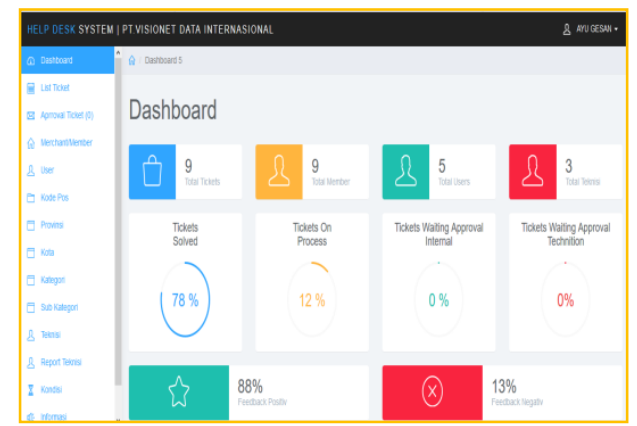

Sumber: Penelitian 2018

Gambar. 13 Menu Utama dan dashboard

c) Form tambah data member

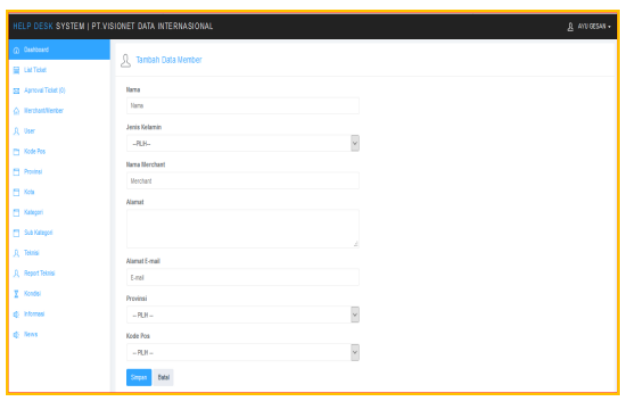

Sumber: Penelitian 2018

Gambar. 14 Form Tambah Member

d) Form tambah User Pengguna

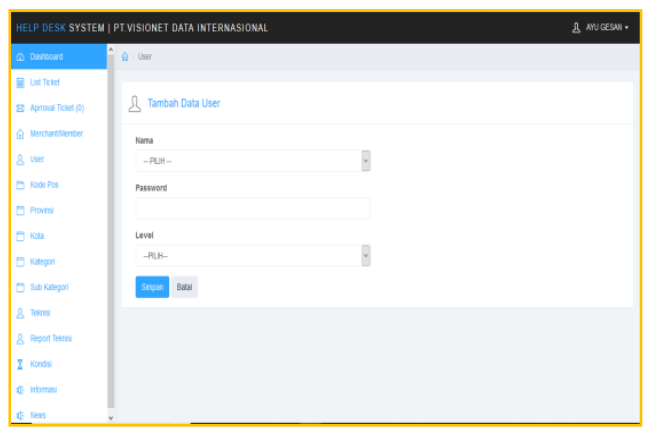

Sumber: Penelitian 2018

Gambar. 15 Form tambah User Pengguna

e) Form membuat tiket laporan

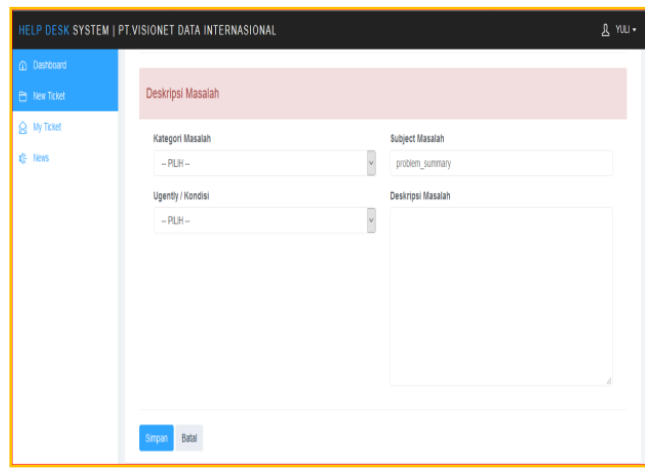

Sumber: Penelitian 2018

Gambar. 16 Form buat Tiket 
f) Menu List Tiket

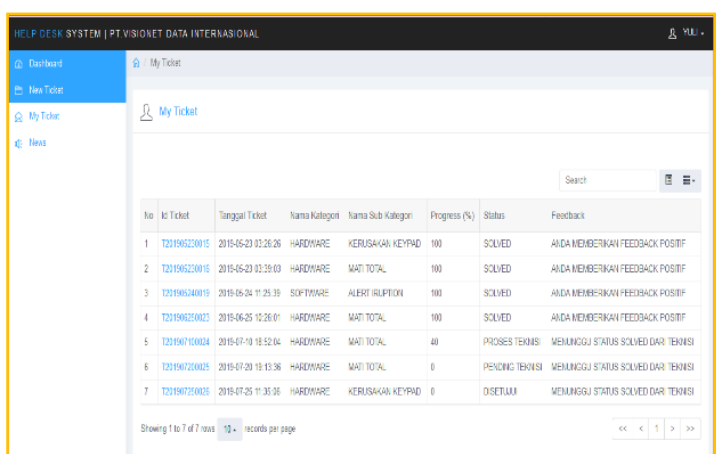

Sumber: Penelitian 2018

Gambar. 17 Menu list tiket

g) Menu List Laporan

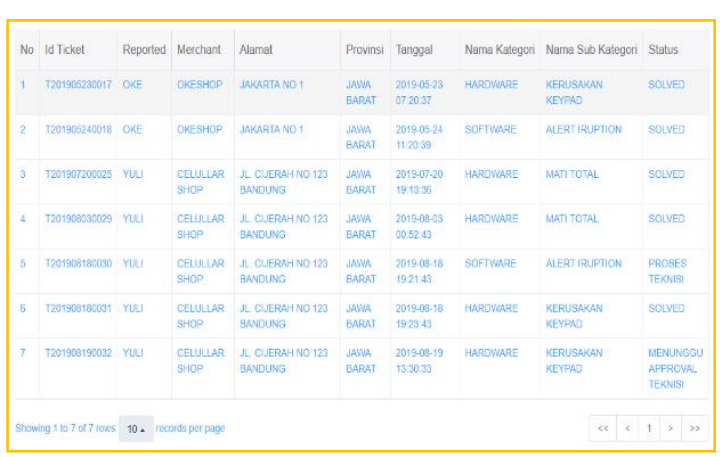

Sumber: Penelitian 2018

Gambar. 18 Menu list tiket

F. Pengujian

Untuk tahap pengujian penulis menggunakan metode Black Box testing, Metode Black Box testing merupakan pengujian program yang mengutamakan pengujian terhadap kebutuhan fungsi dari suatu program.

Tabel 1

Hasil Pengujian Black Box Testing Form Login

\begin{tabular}{|c|c|c|c|c|c|}
\hline No & \begin{tabular}{|l|} 
Skenario \\
Pengujinn \\
\end{tabular} & Test Case & $\begin{array}{c}\text { Hasil yang di } \\
\text { harapkan }\end{array}$ & $\begin{array}{c}\text { Hasil } \\
\text { Pengujinn }\end{array}$ & Kesimpulan \\
\hline 1 & $\begin{array}{l}\text { Usemame } \\
\text { dan } \\
\text { Password } \\
\text { dalam } \\
\text { keadaan } \\
\text { kosong } \\
\text { dan klik } \\
\text { tombol } \\
\text { Login }\end{array}$ & $\begin{array}{l}\text { Usemame:(kosong) } \\
\text { Passivord:(kosong) }\end{array}$ & $\begin{array}{l}\text { Sistem akan } \\
\text { menampilkan } \\
\text { error kolomisi } \\
\text { usernamedan } \\
\text { password field } \\
\text { tidak boleh } \\
\text { kosong }\end{array}$ & $\begin{array}{l}\text { Sesuai } \\
\text { Harapan }\end{array}$ & Valid \\
\hline 2 & \begin{tabular}{|l|} 
Mengisi \\
Username \\
yang tidak \\
terdaftar \\
dan klik \\
tombol \\
Login
\end{tabular} & $\begin{array}{l}\text { Usemame: } \\
\text { K001(tidak } \\
\text { terdaftar) } \\
\text { Password:(kosong) }\end{array}$ & $\begin{array}{l}\text { Sistem akan } \\
\text { menampilkan } \\
\text { error kolomisi } \\
\text { password harus } \\
\text { di isi }\end{array}$ & $\begin{array}{l}\text { Sesuai } \\
\text { Harapan }\end{array}$ & Valid \\
\hline 3 & \begin{tabular}{|l|} 
Mengisi \\
Usemame \\
dengan \\
benar dan \\
Password \\
salah lalu \\
klik \\
tombol \\
Login \\
\end{tabular} & $\begin{array}{l}\text { Usemame: K0013 } \\
\text { (benar) } \\
\text { Password: } 1234 \\
\text { (salah) }\end{array}$ & $\begin{array}{l}\text { Sistem akan } \\
\text { menampilksan } \\
\text { error "Username } \\
\text { Password salah." }\end{array}$ & $\begin{array}{l}\text { Sesuai } \\
\text { Harapan }\end{array}$ & Valid \\
\hline 4 & \begin{tabular}{|l|} 
Mengisi \\
Usemame \\
dan \\
Passiord \\
dengan \\
benar dan \\
klik \\
tombol \\
Login \\
\end{tabular} & $\begin{array}{l}\text { Usemame: K0013 } \\
\text { (benar) } \\
\text { Password: } \\
\text { 123(benar) }\end{array}$ & $\begin{array}{l}\text { Sistem menerima } \\
\text { akses dan manuju } \\
\text { Dashboard } \\
\text { Admin }\end{array}$ & $\begin{array}{l}\text { Sesuai } \\
\text { Harapan }\end{array}$ & Valid \\
\hline
\end{tabular}

Sumber: Penelitian 2018
Tabel 2

Hasil Pengujian Black Box Testing Form Buat Tiket Komplain

\begin{tabular}{|c|c|c|c|c|c|}
\hline No & $\begin{array}{c}\text { Skenario } \\
\text { Pengujian }\end{array}$ & Test Case & $\begin{array}{c}\text { Hasil yang di } \\
\text { harapkan }\end{array}$ & \begin{tabular}{|c|} 
Hasil \\
Pengujinn \\
\end{tabular} & Kesimpulan \\
\hline 1 & $\begin{array}{l}\text { Mengo songkan } \\
\text { kolom isian } \\
\text { dan langsumg } \\
\text { klik tombol } \\
\text { simpan }\end{array}$ & $\begin{array}{l}\text { Semua kolom } \\
\text { isian kosong }\end{array}$ & $\begin{array}{l}\text { Sistem tidak } \\
\text { memproses dan } \\
\text { akan menampilkan } \\
\text { pesan enror pada } \\
\text { tiap kolomyang } \\
\text { kosong }\end{array}$ & $\begin{array}{l}\text { Sesuai } \\
\text { Harapan }\end{array}$ & Valid \\
\hline 2 & $\begin{array}{l}\text { Hanya mengisi } \\
\text { salah satu dari } \\
\text { kolom isian } \\
\text { dan klik } \\
\text { tombol simpan }\end{array}$ & $\begin{array}{l}\text { Mengisi salah } \\
\text { satu kolom } \\
\text { isian pilihan } \\
\text { dan } \\
\text { membiarkan } \\
\text { yanglain } \\
\text { kosong }\end{array}$ & $\begin{array}{l}\text { Sistem tidak } \\
\text { memproses ke } \\
\text { tahap dan akan } \\
\text { menampilkan } \\
\text { pesan error pada } \\
\text { tiap kolom kecuali } \\
\text { kolom yang terisi }\end{array}$ & $\begin{array}{l}\text { Sesuai } \\
\text { Harapan }\end{array}$ & Valid \\
\hline 3 & $\begin{array}{l}\text { Pengisian } \\
\text { kolom dengan } \\
\text { benar danklik } \\
\text { tombol simpan }\end{array}$ & $\begin{array}{l}\text { Memunculkan } \\
\text { variable yang } \\
\text { dibutuhkan } \\
\text { untuk di } \\
\text { tampilkan di } \\
\text { Detail }\end{array}$ & $\begin{array}{l}\text { Sistem memproses } \\
\text { ke tahap detsil dan } \\
\text { menampilkan } \\
\text { laporan } \\
\text { Complain Merchant }\end{array}$ & $\begin{array}{l}\text { Sesuai } \\
\text { Harapan }\end{array}$ & Valid \\
\hline 4 & $\begin{array}{l}\text { Mengisi semua } \\
\text { kolom dengan } \\
\text { benar danklik } \\
\text { Simpan }\end{array}$ & & $\begin{array}{l}\text { Sistem memproses } \\
\text { dan menyimpan } \\
\text { data complainke } \\
\text { database, lahu akan } \\
\text { tampil di memu ny } \\
\text { ticket dengan status } \\
\text { meunggu } \\
\text { persetujuan } \\
\end{array}$ & $\begin{array}{l}\text { Sesuai } \\
\text { harapan }\end{array}$ & Valid \\
\hline
\end{tabular}

Sumber: Penelitian 2018

Tabel 3

Hasil Pengujian Black Box Testing Form Tambah User

\begin{tabular}{|c|c|c|c|c|c|}
\hline $\mathrm{N}_{0}$ & $\begin{array}{l}\text { Skenario } \\
\text { Pengujian }\end{array}$ & Test Case & $\begin{array}{c}\text { Hasil yang di } \\
\text { harapkan }\end{array}$ & $\begin{array}{c}\text { Hasil } \\
\text { Pengujian }\end{array}$ & Kesimpulan \\
\hline 1 & $\begin{array}{l}\text { Mengosongkan } \\
\text { kolom isian } \\
\text { dan langsung } \\
\text { klik tombol } \\
\text { simpan }\end{array}$ & $\begin{array}{l}\text { Semuakolom } \\
\text { isiankosong }\end{array}$ & \begin{tabular}{|l|} 
Sistem tidak \\
memproses dan \\
akan \\
menampillkan \\
pesan enor pada \\
tiap kolomyang \\
kosong \\
\end{tabular} & $\begin{array}{l}\text { Sesuai } \\
\text { Harapan }\end{array}$ & Valid \\
\hline 2 & $\begin{array}{l}\text { Hanya mengisi } \\
\text { salah satudani } \\
\text { kolom isian } \\
\text { dan klik } \\
\text { tombol simpan }\end{array}$ & $\begin{array}{l}\text { Mengisi salah } \\
\text { satukolom isian } \\
\text { pilihan dan } \\
\text { membiarkan } \\
\text { yang lain kosong }\end{array}$ & $\begin{array}{l}\text { Sistem tidak } \\
\text { memproses ke } \\
\text { tahap dan aksan } \\
\text { menampillkan } \\
\text { pesan enor pada } \\
\text { tiap kolom } \\
\text { kecualikolom } \\
\text { yang terisi }\end{array}$ & $\begin{array}{l}\text { Sesuai } \\
\text { Harapan }\end{array}$ & Valid \\
\hline 3 & $\begin{array}{l}\text { Pengisian } \\
\text { kolom dengan } \\
\text { benar danklik } \\
\text { tombol simpan }\end{array}$ & $\begin{array}{l}\text { Semuakolom } \\
\text { diisi }\end{array}$ & \begin{tabular}{|l|} 
Sistem \\
memproses ke \\
tahap beriluturya \\
dan \\
menampillkan \\
data baru list \\
user
\end{tabular} & $\begin{array}{l}\text { Sesuai } \\
\text { Harapan }\end{array}$ & Valid \\
\hline
\end{tabular}

Sumber: Penelitian 2018 
Tabel 4

Hasil Pengujian Black Box Testing Form Tambah Member

\begin{tabular}{|c|c|c|c|c|c|}
\hline $\mathrm{N}_{0}$ & $\begin{array}{l}\text { Skenario } \\
\text { Pengujian }\end{array}$ & Test Case & $\begin{array}{c}\text { Hasil yang di } \\
\text { harapkan }\end{array}$ & \begin{tabular}{|c|} 
Hasil \\
Pengujinn \\
\end{tabular} & Kesimpulan \\
\hline 1 & $\begin{array}{l}\text { Mengosongkan } \\
\text { kolom isian } \\
\text { dan langsung } \\
\text { klik tombol } \\
\text { simpan }\end{array}$ & $\begin{array}{l}\text { Semua kolom } \\
\text { isian kosong }\end{array}$ & \begin{tabular}{|l|} 
Sistem tidak \\
memproses dan \\
akan \\
menampilkan \\
pesan enor pada \\
kolom yang \\
kosong \\
\end{tabular} & $\begin{array}{l}\text { Sesuai } \\
\text { Harapan }\end{array}$ & Valid \\
\hline 2 & $\begin{array}{l}\text { Hanya mengisi } \\
\text { salah satu dari } \\
\text { kolom isian } \\
\text { dan klik } \\
\text { tombol simpen }\end{array}$ & $\begin{array}{l}\text { Mengisi salah } \\
\text { satu kolomisian } \\
\text { pilihan dan } \\
\text { membiarkan } \\
\text { yanglain ko ong }\end{array}$ & $\begin{array}{l}\text { Sistem tidak } \\
\text { memproses ke } \\
\text { tahap dan akan } \\
\text { menampilkan } \\
\text { pesan enor pada } \\
\text { kolom kecuali } \\
\text { kolom yang } \\
\text { terisi }\end{array}$ & $\begin{array}{l}\text { Sesuai } \\
\text { Harapan }\end{array}$ & Valid \\
\hline 3 & $\begin{array}{l}\text { Pengisian } \\
\text { kolom dengan } \\
\text { benar danklik } \\
\text { tombol simpan }\end{array}$ & $\begin{array}{l}\text { Semuakolom } \\
\text { diisi }\end{array}$ & \begin{tabular}{|l|} 
Sistem \\
memproses ke \\
tahap berihuthya \\
dan \\
menampilkan \\
data baru List \\
Merchant \\
\end{tabular} & $\begin{array}{l}\text { Sesuai } \\
\text { Harapan }\end{array}$ & Valid \\
\hline
\end{tabular}

Sumber: Penelitian 2018

\section{KESIMPULAN}

Dalam proses penelitian yang dilakukan penulis untuk pembuatan sistem informasi layanan pelaporan kerusakan mesin EDC, maka penulis berkesimpulan bahwa dengan adanya system informasi layanan pelaporan kerusakan mesin EDC tersebut akan mempermudah untuk pelanggan dalam pembuatan laporan secara cepat. Dan dalam penyelesaiannya dapat diketahui nama teknisi yang ditugaskan karena untuk menghindari kejahatan contoh mengaku teknisi dari Visionet namun nama berbeda. Disamping itu pihak pelanggan bisa mengetahui proses dari perbaikan sejauh mana sudah dikerjakan. Sehingga memberikan kemudahan bagi karyawan membuat laporan, mengefesiensikan waktu proses pengerjaannya serta mempermudah dalam mengetahui penyebab sering terjadinya permasalahn pada mesin EDC dan dapat mengurangi resiko EDC tidak dapat digunakan dalam jangka waktu yang lama.

\section{REFERENSI}

Agus, P., \& Safitri, Y. (2015). Pemanfaatan Sistem Informasi Perpustakaan Digital Berbasis Website Untuk Para Penulis Agus Prayitno 1) Yulia Safitri 2). Indonesian Journal on Software Engineering, 1(1), 1-10. Retrieved from

https://ejournal.bsi.ac.id/ejurnal/index.php/ijse /article/viewFile/592/483
Amin, R. (2016). Sistem Informasi Helpdesk Berbasis Web Pada Pt . Sisindokom Lintasbuana. 15-20. Retrieved from https://konferensi.nusamandiri.ac.id/proceedin g/index.php/KNIT/article/view/4

Cermati.com. (2019). Mesin EDC, Ini Cara Kerja dan Tips Penggunaannya! Retrieved from www.cermati.com website: https://www.cermati.com/artikel/mesin-edcini-cara-kerja-dan-tips-penggunaannya

Darmawan, D., \& Senjaya, W. (2017). Sistem Aplikasi Helpdesk Online Berbasis Web Pada Pt Xyz. Teknik Dan Ilmu Komputer, 07 No. 25(November 2017), 79-96. https://doi.org/10.1523/JNEUROSCI.443212.2013

Gonius, N. (2013). Study Deskriptif Tentang Customer Complaints Di Restoran Wok Noodles Di Galaxy Mall Surabaya. 2(1), 1-15. Retrieved from https://scholar.google.co.id/scholar?hl=id\&as_ $\mathrm{sdt}=0 \% 2 \mathrm{C} 5 \&$ as_vis $=1 \& \mathrm{q}=$ Study+Deskriptip+ Tentang+Customer+Complaints+Di+Restoran $\& b \operatorname{tnG}=$

Irawan, A., \& Setiyorini, N. K. (2017). Rancang Bangun Aplikasi helpdesk Dengan Menggunakan Pendekatan Knowledge Management System Pada Seksi Teknisi pt. Indah kiat pulp \& paper tbk. Jurnal ProTekInfo, 4.

Muhidin, R., Kharie, N. F., \& Kubais, M. (2017). Analisis dan Perancangan Sistem Informasi pada SMA Negeri 18 Halmahera Selatan sebagai Media Promosi Berbasis Web. Indonesian Journal on Information System (IJIS), 2(2), 56-68. Retrieved from https://www.neliti.com/id/publications/260159 /analisis-dan-perancangan-sistem-informasipada-sma-negeri-18-halmahera-selatan-s

Nugroho, A., Safirman, M. R., Studi, P., \& Informatika, T. (2015). Perancangan sistem aplikasi rekam medik pada puskesmas pakuan baru kota jambi. 10(1), 406-412. Retrieved from http://ejournal.stikomdb.ac.id/index.php/processor/article/view/93

Rosa, A. ., \& Shalahuddin, M. (2018). Rekayasa Perangkat Lunak Terstruktur dan Berorientasi Objek. Bandung: Informatika

Syukron, A., \& Hasanah, N. (2015). Perancangan Sistem Informasi Rawat Jalan Berbasis Web Pada Puskesmas Winong. Jurnal Bianglala Informatika, 3(1), 28-34. Retrieved from http://ejournal.bsi.ac.id/ejurnal/index.php/Bian glala/article/view/574 